\title{
Sosialisasi Mitigasi dan Game Gempa Bumi Pada Panti Asuhan Dharma Jati Kecamatan Denpasar Timur Provinsi Bali
}

\author{
Nia Maharani ${ }^{1}$, Evi Dwi Krisna ${ }^{2}$ \\ STMIK STIKOM Indonesia Bali \\ E-mail: maharani.nst@ gmail.com
}

\section{Article History: \\ Received: Oktober \\ Revised: Oktober \\ Accepted: November \\ Available online: Desember}

Kata Kunci: Bencana gempa bumi, Lempeng tektonik, Sosialisasi

\begin{abstract}
Abstrak:
Panti Asuhan Dharma Jati merupakan salah satu panti asuhan yang terletak di Kecamatan Denpasar Timur Kota Denpasar merupakan salah satu panti asuhan yang terkena guncangan gempa bumi tahun 2019. Setelah kejadian gempa terakhir itu belum ada sosialisasi tentang gempa bumi dan langkahlangkah yang harus dilakukan apabila terjadi gempa bumi. Metoda yang digunakan dalam kegiatan pengabdian ini adalah metoda ceramah yang dilengkapi dengan sesi tanya jawab dan game atau tes kecil. Game berisi pertanyaan-pertanyaan acak yang diberikan langsung dan oleh nara sumber dan dijawab secara langsung oleh para peserta. Game sebelum dan sesudah kegiatan pengabdian menunjukan hasil bahwa ada peningkatan pengetahuan dan pemahaman gempa dan mitigasi nya dari $25 \%$ yang menjawab benar menjadi $75 \%$.
\end{abstract}




\section{Pendahuluan}

Gempa bumi merupakan bencana alam yang relatif sering terjadi di Indonesia, terutama akibat interaksi lempeng tektonik (Astuti, 2020). Indonesia merupakan negara kepulauan yang terletak pada pertemuan 4 (empat) lempeng tektonik dunia, yaitu lempeng Eurasia; lempeng Australia; lempeng Pasifik; dan lempeng Filipina. Lempeng Australia dan lempeng Pasifik merupakan jenis lempeng samudera yang bersifat lentur, sedangkan lempeng Eurasia berjenis lempeng benua yang bersifat rigid dan kaku. Pertemuan lempeng tektonik tersebut menyebabkan terjadinya penunjaman serta patahan aktif di dasar lautan dan di daratan. Aktifitas zona tumbukan dan patahan-patahan tersebut berpotensi memicu terjadinya gempa bumi (Pribadi et.al., 2008).

Kesiapsiagaan merupakan hal yang penting dan harus dibangun pada setiap kelompok di masyarakat (Arisona, 2020). Pengalaman menunjukkan bahwa kehancuran akibat bencana dapat dikurangi secara drastis jika semua orang lebih siap menghadapi bencana (Nurjannah et.al., 2019). Sekolah adalah pusat pendidikan yang tidak hanya memberikan ilmu pengetahuan namun juga bekal untuk kelangsungan hidup (Meutia et.al, 2019). Anak-anak merupakan peserta ajar yang paling cepat dan tidak hanya mampu memadukan pengetahuan baru ke dalam kehidupan sehari-hari tetapi juga menjadi sumber pengetahuan bagi keluarga dan masyarakat dalam hal perilaku yang sehat dan aman yang didapatkan disekolah (Maharani, 2020). Oleh karena itu, pencegahan bencana menjadi salah satu fokus di sekolah dengan memberdayakan anak-anak dan remaja untuk memahami tanda-tanda peringatan bencana dan langkah-langkah yang dapat diambil untuk mengurangi resiko dan mencegah bencana (Nuraeni et.al, 2020).

Bali merupakan salah satu pulau di Indonesia yang memiliki potensi gempa bumi. Ada tiga sumber utama potensi gempa dan tsunami di Bali yaitu di bagian utara laut Bali, Kecamatan Seririt, Kabupaten Buleleng dan bagian selatan Bali. Gempa yang pernah terjadi tanggal 13 Oktober 2011 dibagian selatan Bali dengan kekuatan 6.8. Episenter terletak di $143 \mathrm{~km}$ arah barat Nusa Dua. Gempa ini juga dirasakan di Yogyakarta, Mataram dan Malang. Puluhan 
orang dikabarkan luka-luka. Gempa ini tidak menyebabkan tsunami tetapi menimbulkan beberapa kerusakan banyak bangunan di Denpasar dan, Kuta dan Nusa Dua bahkan melebar atau meluas sampai ke Banyuwangi sampai Jember ada banyak kerusakan ringan dan menyebabkan kerugian mencapai 727 juta Rupiah. Kemudian masih pada pusat yang sama tanggal 16 Juli 2019 gempa kembali terjadi dengan magnitudo 5.8. BMKG mencatat sebanyak 14 kali gempa susulan dengan magnitudo 2.4 hingga 3.5. Gempa ini merupakan bagian dari rangkaian gempa bumi Bali akibat aktivitas subduksi lempeng Indo-Australia. Dari kejadian-kejadian diatas tersebut maka sudah sepantasnya melalui pendidikan diharapkan agar upaya pengurangan resiko bencana dapat mencapai sasaran yang lebih luas dan dapat dikenalkan secara lebih dini kepada seluruh peserta didik (Utomo et.al, 2019). Banyaknya korban jiwa dan kerugian material yang diakibatkan karena rendahnya tingkat kesiapsiagaan dan minimnya pengetahuan tentang gempa bumi itu (Maharani, et.al, 2020).

Hasil survei di Jepang pada kejadian gempa Great Hanshin Awaji 1995 menunjukkan bahwa persentase korban selamat disebabkan oleh diri sendiri sebesar 35\%. Anggota keluarga 31,9\%, teman / tetangga 28,1\%, orang lewat 2,60\%, Tim SAR 1,70\% dan lain-lain 0,90\% (BNPB, 2017). Mencermati hal ini, maka upaya penyelamatan diri sendiri sejak awal patut mendapat perhatian untuk dapat mengurangi jumlah korban jiwa akibat gempa bumi.

Panti Asuhan Dharma Jati merupakan salah satu panti asuhan yang terletak di Kecamatan Denpasar Timur Kota Denpasar merupakan salah satu panti asuhan yang terkena guncangan gempa bumi tahun 2019. Setelah kejadian gempa terakhir itu belum ada sosialisasi tentang gempa bumi dan langkah-langkah yang harus dilakukan apabila terjadi gempa bumi. Dari uraian diatas maka salah satu solusi yang dapat diberikan adalah memberikan pengetahuan dasar tentang gempa bumi dan langkah-langkah yang harus dilakukan terutama pada saat terjadinya gempa bumi pada anak-anak panti asuhan Dharma Jati. Kegiatan sosialisasi ini diharapakan nantinya dapat membantu anak-anak panti asuhan Dharma Jati Denpasar apabila suatu waktu terjadi bencana gempa bumi maka para peserta diharapkan sudah siapsiaga. 


\section{Metode}

Kegiatan PKM ini diadakan selama 1 (satu) hari yaitu tanggal 29 Agustus 2020 bertempat di Panti Asuhan Dharma Jati, Desa Penatih Kecamatan Denpasar Timur Kota Denpasar Provinsi Bali seperti terlihat pada gambar 1. Area yang digunakan pada panti asuhan adalah aula. Penanggung jawab kegiatan yaitu satu orang dosen dari Program studi Sistem Komputer dan satu orang dosen dari Jurusan Manajemen Teknik Informatika serta dibantu oleh dua orang mahasiswa. Target pengabdian yaitu anak-anak panti asuhan Dharma Jati.

Adapun kegiatan yang dilakukan adalah berupa sosialisasi bencana gempa bumi yang dilakukan terhadap 12 orang anak panti asuhan dengan latar belakang pendidikan sekolah dasar sampai sekolah menengah atas. Peserta sosialisasi diberikan pemahaman dan pengetahuan dalam rangka meningkatkan kapasitasnya dalam menghadapi bencana gempa bumi dan setelah itu dilakukan tanya jawab antara siswa-siswi dan penyaji materi. Terakhir adalah kuis gempa bumi yang berkaitan dengan apa yang sudah dijelaskan sebelumnya.

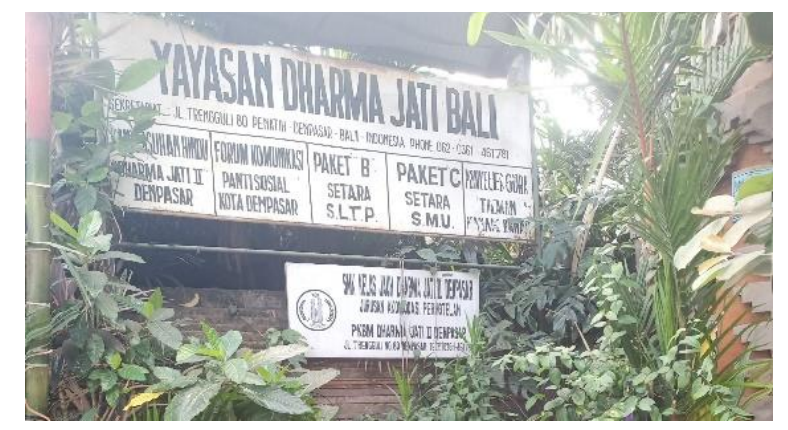

Gambar 1. Panti Asuhan Dharma Jati Denpasar Timur. 


\section{Hasil}

Kegiatan ini berisi tentang sosialisasi mengenai bencana gempa bumi kepada anak-anak panti asuhan yang berjumlah 12 orang. Berdasarkan informasi yang didapat bahwa sebelumnya belum ada kegiatan sosialisasi yang dilaksanakan di panti asuhan tersebut. Hal ini ditunjukkan dari hasil tes kecil berupa pertanyaan dasar seperti pengertian gempa, jenis-jenis gempa bumi dan mitigasi yang diberikan secara langsung dan langsung dijawab oleh masing-masing peserta. Dari hasil tes kecil tersebut hanya 3 orang peserta saja yang menjawab benar atau $25 \%$. Dari hasil tersebut terlihat bahwa pengetahuan dan pemahaman peserta terhadap bencana gempa dan mitigasinya masih kurang.

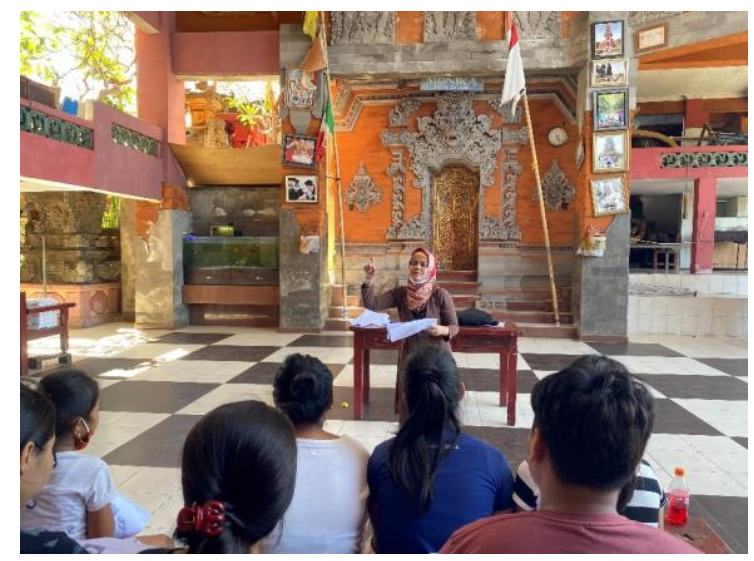

Gambar 2. Pembukaan Kegiatan Sosialisasi.

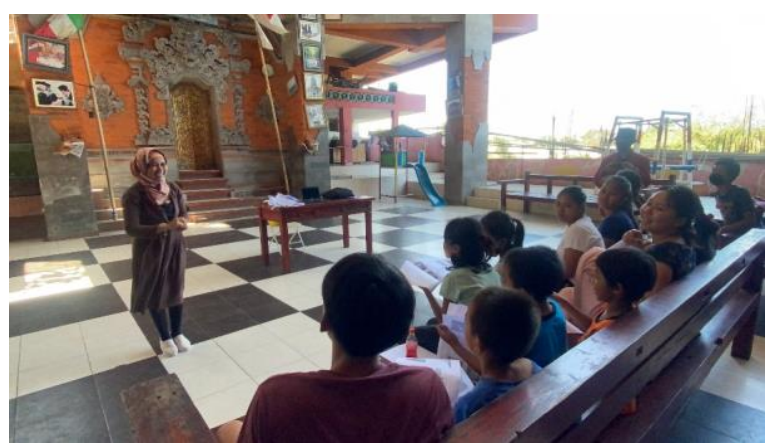

Gambar 3. Pemaparan Gempa Bumi. 
Kegiatan selanjutnya setelah tes kecil di awal adalah pengetahuan dasar dan antisipasinya dipaparkan dalam bentuk presentasi oleh nara sumber seperti terlihat pada gambar 2 dan dilanjutkan dengan tanya-jawab yang dilakukan oleh anak-anak panti asuhan. Kegiatan ini diikuti dengan tertib oleh semua anak-anak panti asuhan dan begitu antusiasnya para peserta dalam mendengarkan penjelasan dari pemateri seperti terlihat pada gambar 3 . Suasana kelas begitu hidup disaat beberapa peserta begitu semangat memberikan pertanyaan-pertanyaan seperti terlihat pada gambar 4. Adapun kegaiatan setelah sesi tanya jawab yaitu melakukan game atau tes kecil. Pada dasarnya tes kecil ini sama seperti tes kecil di awal bertujuan untuk melihat sejauh mana pemahaman para peserta terhadap materi yang dipaparkan oleh nara sumber. Dari hasil tes menunjukkan 9 orang yang benar menjawab pertanyaan-pertanyaan atau $75 \%$ dari total peserta sosialisasi. Hasil tersebut menunjukkan adanya peningkatan pengetahuan dan pemahaman terhadap bencana dan mitigasi gempa bumi. Gambar 5 adalah salah satu peserta menjawab soal game gempa bumi. Mengapa tes kecil ini disebut game karena peserta yang paling banyak menjawab pertanyaan dengan benar akan mendapatkan hadiah. Semua pertanyaan yang diberikan bersifat acak.

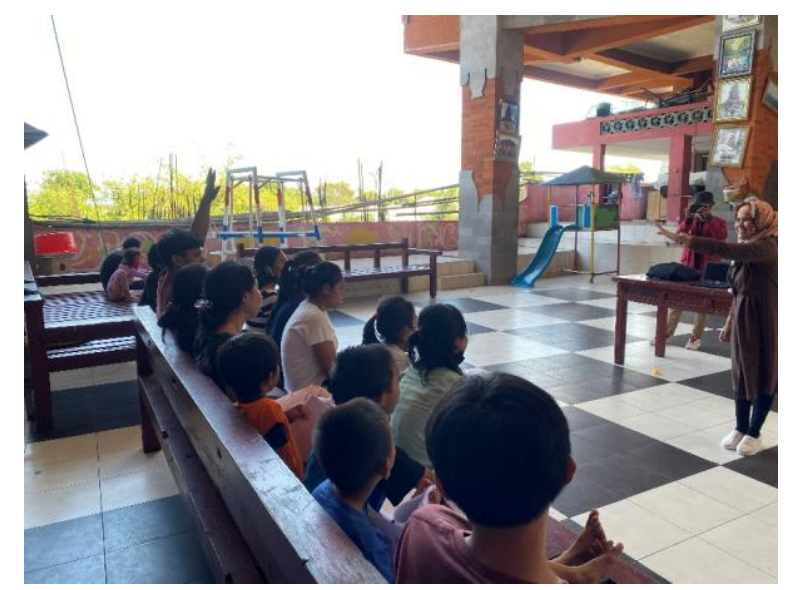

Gambar 4. Peserta Mengajukan Pertanyaan Pada Sesi Diskusi. 


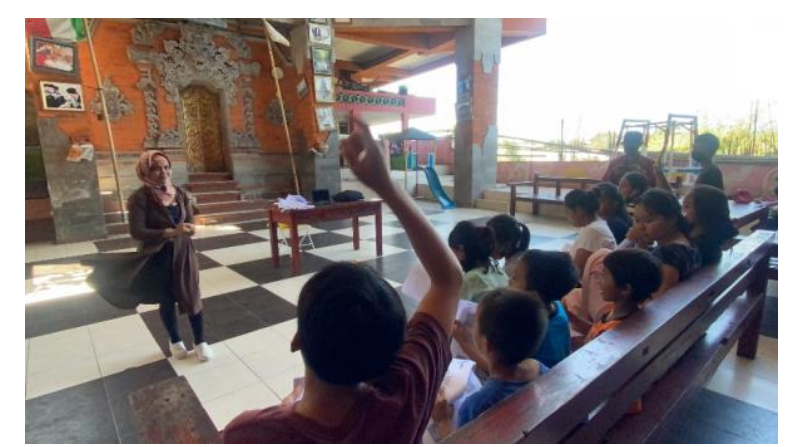

Gambar 5. Peserta memberikan jawaban Game.

\section{Diskusi}

Dari hasil kegiatan pengabdian masyarakat ini terlihat bahwa tahapan awal yaitu tes kecil atau pra tes dapat melihat bagaimana tingkat pengetahuan dan pemahaman para peserta yaitu anak-anak panti tentang gempa dan mitigasinya. Hasilnya yaitu kurangnya pengetahuan anak-anak panti tentang bencana gempa. Hasil ini sesuai dengan observasi lapangan yaitu di panti Dharma Jati belum pernah dilakukan sosialisasi gempa dan mitigasinya yang berupa pemaparan. Setelah dilakukan pemaparan dan diakhiri dengan game atau tes kecil di akhir, pemahaman para peserta menjadi lebuh baik. Adapun Adapun inti dari pemaparan tersebut adalah membaas tentang definisi gempa bumi dimulai dari yang dasar dulu, dilanjutkan dengan jenis-jenis gempa bumi dan mitigasi gempa bumi saat berada di suatu tenpat tertentu. Ditinjau lebih detail anak-anak panti asuhan memiliki latar belakang pendidikan yag berbeda dimulai dari tingkat SD sampai SMA. Proses pembelajaran formal dilaksanakan dipanti dengan mendatangkan guru. Jadi bisa dikatakan kegiatan sosialisasi ini adalah kegiatan pertama anak panti dimana panti menjadi tempat belajar formal maupun non formal bagi mereka semua. Anak-anak pada jenjang sekolah merupakan aset awal dalam menanamkan akan pengetahuan dan kesiapsiagaan bencana gempa itu sendiri melalui sosialisasi (Meutia dkk, 2019). Rangkaian kegiatan ini diharapkan berlangsung secara berkesinambungan dalam rangka menyiapkan generasi anak didik untuk menghad api bencana gempa bumi. 


\section{Kesimpulan}

Kegiatan sosialisasi bencana gempa bumi melalui metoda ceramah dan tanya-jawab dan permainan/game dapat diikuti dengan baik oleh seluruh peserta dengan antusias dan sangat interaktif. Hal tersebut dapat dilihat dari game atau tes kecil yang dilakukan sebelum dan sesudah kegiatan sosialisasi. Sebelum kegiatan sosialisasi dimulai hanya 3 orang atau 25\% saja yang menjawab pertayaan dengan benar. Setelah sosialisasi peserta yang dapat menjawab benar pertanyaan adalah 9 orang atau sekitar $75 \%$ dari seluruh jumlah peserta. Adanya peningkatan pemahaman tentang gempa bumi dan mitigasi tersebut diharapkan bisa diterapkan dalam kehidupan sehari-hari dalam menghad api bencana gempa bumi.

\section{Saran}

Perlu kegiatan lanjutan yaitu simulasi gempa bumi di Panti Asuhan Dharma Jati Denpasar sebagai rangkaian kegiatan sosialisasi gempa bumi. Simulasi gempa bumi bisa dilakukan dengan media berbasis Virtual Reality menggunakan kaca mata 3-D. Media tersebut bisa mendesain sendiri atau menonton langsung dari Youtube.

\section{Daftar Referensi}

Arisona, R. D. (2020). SOSIALISASI DAN SIMULASI MITIGASI BENCANA GEMPA BUMI DALAM MENINGKATKAN KESIAPSIAGAAN SISWA SDN 2 WATES PONOROGO. ASANKA: Journal of Social Science And Education, 1(1), 1-7.

Rahma, A. (2018). Implementasi program pengurangan risiko bencana (PRB) melalui pendidikan formal. Jurnal VARIDIKA, 30(1), 1-11.

BNPB (2017.)Tanggap Tangkas Menghadapi Bencana 13. Jakarta: Badan Nasional Penanggulangan Bencana

Khrisna.S, Pribadi.v (2008). Pendidikan Siaga Bencana ITB. Program Kesiapan Sekolah Terhadap Bahaya Gempa Bumi,Bandung : Institut Teknologi Bandung

Maharani, N., Khaerismawati, N. P. E., \& Sari, N. L. P. W. (2020). SOSIALISASI DAN SIMULASI GEMPA BUMI DI SMPN 3 KUTA SELATAN BADUNG BALI. Jurnal Bakti Saraswati (JBS): Media Publikasi Penelitian dan Penerapan Ipteks, 9(1), 31-37.

Maharani, N. (2020). Tingkat Pengetahuan Siswa Tentang Kesiapsiagaan 
Bencana Gempa Bumi Di SMPN 3 Kuta Selatan Badung Provinsi Bali. PENDIPA Journal of Science Education, 4(3), 32-38.

Farida, M., Alimuddin, I., Maulana, A., Irfan, U. R., \& Jaya, A. (2019). Sosialisasi Bencana Geologi dan Mitigasinya di Sekolah Dasar Islam Terpadu (SDIT) Ar-Rahmah Makassar. JURNAL TEPAT: Applied Technology Journal for Community Engagement and Services, 2(2), 66-73.

Nurjanah, Sugiharto R., Kuswanda Dede, BP Siswanto, Adikoesoemo (2012). Manajemen Bencana, Bandung : ALFABETA,

Nuraeni, N., Mujiburrahman, M., \& Hariawan, R. (2020). Manajemen Mitigasi Bencana pada Satuan Pendidikan Anak Usia Dini untuk Pengurangan Risiko bencana Gempa Bumi dan Tsunami. Jurnal Penelitian dan Pengkajian Ilmu Pendidikan: e-Saintika, 4(1), 68-79.

Utomo, L. P., Saputra, I. A., Rahmawati, R., \& Nisa, Z. SOSIALISASI KESIAPSIAGAAN SISWA DALAM MENGHADAPI BENCANA GEMPA BUMI DI SMA AL-AZHAR MANDIRI PALU. Jurnal Pengabdian Pada Masyarakat, 7(2), 43-51. 